\title{
Seismic Risk for the Largest Cities of the World ; Intensity VIII or More *
}

\author{
by V. I. Keilis-Borok, T. L. Kronrod and G. M. Molchan **
}

\begin{abstract}
General methodology of probabilistic estimation of seismic risk, as a base for decision making, is described by an analysis of seismic risk for the cities with population $\geqslant 1 \mathrm{mln}$ in active seismic regions of the world.

The estimations are based on seismotectonic regionalization of the world and on the three models: of earthquake occurrence, strong motion (isoseists) and dynamics of population. The estimations are tested by comparison with actual earthquake history of the cities considered.

The test is successful, in spite of the fact, that all these models are grossly averaged due to the usual incompleteness of the data. This shows, that available data may be sufficient to estimate the seismic risk for a large set of objects, while not for each separate object.

During the 30 years, $1971-2000,8 \pm 3.5$ cities and $40.1 \pm 21.6$ mlns of people in these cities will experience strong motions with macroseismic intensity $\geqslant$ VIII MM (Modified Mercalli Scale). Counted are only the events, when such shaking covers $\geqslant 100 \mathrm{~km}^{2}$, so that each event does spell disaster. The second estimation is large due to the explosion of urban population. More conservative data on the population growth reduce this estimation not more, than by $30 \%$. It indicates, that global seismic risk is rapidly increasing, presenting new unexplored problems.
\end{abstract}

\section{Outline of methodology}

Estimations of seismic risk are the necessary base for decision-making, concerning prevention and mitigation of the damage from the earthquakes. Under the present state

* This is a reduced version of the study. The full version is published in the "Etudes et Dossiers" N. 77, February 1984, of the Geneva Association.

** Institute of the Physics of the Earth, Academy of Sciences, USSR, 123242 Moscow, B. Gruzinskaya 10. 
of art - including dominant psychology of the studies - the methodology of these estimations can be best described on concrete examples. This paper and the subsequent one describe two insurance-oriented examples. They concern the opposite ends of the wide spectrum of the problems, presented by earthquake insurance. One is the seismic risk for major cities, where only the economy losses inflicted by a single earthquake may reach $\$ 100$ billions $[1,2]$, challenging the capacity of the world's reinsurance. The second problem is the fair earthquake insurance rate for rural areas, with smaller, though significant, potential damage. The results, obtained for the first problem, seem to be of general interest indicating the steep ascend and changing nature of global seismic risk.

In both papers we use the conception, methods and assumptions, described in [3-5], together with corresponding computers software. Similar to some extent methodology was developed by R. Whithman, A. Cornell and their associates at Department of Civil Engineering, Massachusetts Institute of Technology ; it is described in the series of reports on Seismic Design Decision Analysis.

a) The formulation of the problem. The nature of decisions, regarding prevention and mitigation of seismic risk requires, that the data, relevant to seismic risk, are compressed into the probability of the damage from the earthquakes:

$$
F_{\Sigma}\left(D / T_{1}, T_{2} ; S\right)
$$

Here $F$ is the probability distribution function; it shows the conditional probability, that the damage $D$ from all the earthquakes during the time period from $T_{1}$ to $T_{2}$ will exceed $D$. $S$ symbolises the set of the executed safety measures.

Decision making regarding risk of any hazard is traditionally based on such distribution functions, especially in connection with the insurance. Seismic risk, due to certain unfortunate circumstances, presented an exception for a long time: it was characterized by a maximal possible strong motion, or, later, by frequency-of-occurrence of strong motions with different intensity.

b) The objects. The nature of the problem requires, that seismic risk is estimated for specific objects. Following are the types of the objects, considered by the algorithm :

a) combination of points - for example, buildings or small towns ;

b) combination of lines - for example, lifelines ;

c) combination of two-dimensional areas - for exaınple, economic regions, large cities, etc. ;

d) any combination of objects of types a, b, c.

c) The damage. Different measures of the damage have to be considered under different circumstances.

The following two measures are of main importance, since they directly characterize the losses inflicted by earthquakes :

1. Number of casualties: (a) total number; (b) the reduction achieved by safety measures. 
2. Economic losses from earthquakes: (a) total losses; (b) losses prevented by safety measures. Let us clarify the meaning of this effect. In the course of a period of time studied, earthquakes occur. During each earthquake there is a possibility of loss. The sum of these losses is effect $2 \mathrm{a}$. Part of the loss will be prevented; the sum of the prevented loss is effect $2 b$. The following measures indirectly characterize the losses:

3. Total number of people present in the zones of a given intensity of strong motion.

4. Total value of property present in such zones.

5. Total count of the objects, present in such zones. For point objects this is the number of points experiencing strong motion; for lines or two-dimensional objects respectively the sum of the segments or areas experiencing strong motions.

The probability of total loss $1 \mathrm{a}, 2 \mathrm{a}$ is the direct measure of seismic risk. It is necessary to know also the probability of prevented loss $1 \mathrm{~b}, 2 \mathrm{~b}$ in order to optimize safety measures. Characteristics 3-5 give only an indirect idea of seismic risk (for example, the total value of property affected by strong motions only indirectly characterizes the possible losses). However, these indirect characteristics can be useful for preliminary analysis, especially since their calculation requires fewer data.

d) Models. In order to estimate seismic risk, it is necessary first to establish the following models: of the earthquakes sequence; of the strong motion from a single earthquake; of the "local" damage, i.e. the damage caused by a given strong motion during a single earthquake. The necessity of these models is the trait of the problem itself, and not of the particular method we use.

The data on strong earthquakes are rather limited, so that only crude models can be established at present. However, crude estimates of seismic risk are sufficient for making many practical decisions. And, in any case, the suggested method allows to estimate the accuracy of the models, and thus to avoid unfounded decisions.

These models were so far represented as follows :

e) A model of earthquakes sequence is represented by distribution functions of random values $N\left(G_{k}, M_{l}, T\right) . N$ is the number of earthquakes that can take place in $T$ years in $M_{l}$ range of magnitude in regions $G_{k}, k, l=1,2, \ldots$

These regions are defined by condition, that the distribution function of $N$ has common parameters within each region. Accordingly, seismotectonic regionalization is a necessary preliminary stage.

An additional assumption is that the earthquakes in non-intersecting volumes (space - time - energy) are statistically independent; therefore the total number of earthquakes has the Poissonian distribution (after elimination of aftershocks).

f) Model of strong motions, generated by one earthquake. This model establishes the random values $I(g, \tilde{g}, M)$. Here $I$ is the intensity of strong motion at point $\tilde{g}$ during an earthquake with hypocenter at point $g$ and with magnitude $M$.

The suggested method applies to any measures of intensity. However, in practice we have yet only been successful in collecting enough material for strong motions in 
macroseismic scale. Hence the model comes down to a model of isoseismals. Its parameters are random values, whose distribution depends on $g, \tilde{g}, M$.

An additional assumption is that with homogeneous soil conditions isoseismals are concentric elipses. Their parameters (area, elongation, azimuth of long axis) are random values, the distribution of which depends on the magnitude and coordinate of the epicenter. The average azimuth of the long axis coincides with the strike of the major faulting.

g) Model of local damage is based on three assumptions : the damage inflicted on a given object in a given point during a single earthquake depends on the intensity of strong motion only in this point and on the time of the earthquake; the total damage from a single earthquake is the sum of the values of the damage in each point; the values of damage from different earthquakes are statistically independent.

Accordingly, we have for the total damage

$$
D=\sum_{T_{1} \leqslant t_{i} \leqslant T_{2}} d_{i}, d_{i}=\sum_{p} d_{i p} \exp \left\{k\left(t_{i}-t_{0}\right)\right\}
$$

where $d_{i}$ is the damage, caused by the $i$-th earthquake ; $t_{i}$ - time of this earthquake; $d_{i p}$ is the "local" damage in the $p$-th element of the object: exponential factor reduces the damage to a common time and/or allows for time - dependance of damage. We usually represented the local damage as deterministic function of strong motion. The probabilistic function - damage probability matrix - was introduced in pioneering work by $\mathrm{R}$. Witman and A. Cornell in the above mentioned reports. It is more adequate, but requires much more data. Obviously, the damage depends on the safety measures.

h) The algorithm consists of three following parts.

I : In the memory of a computer the image of the studied territory is constructed. It defines : for each point of the region - parameters of the first two models (earthquakes sequence and strong motion); for each point of the object - parameters of the model of the local damage. region.

Actually, the image includes the contours of the regions and parameters for each

\section{II : Distribution function $F(x)$ of the damage from a single earthquake is estimated.}

Let us clarify the idea of this function. An earthquake with fixed characteristics (hypocentre, magnitude and isoseists) produces certain damage. It is determined as a sum of the values of damage at each point of each objects. The above characteristics of earthquakes are random. Thus the total damage from a single earthquake is also a random value. The distribution of this value is evaluated in this part of the calculations. The general scheme of calculation follows.

In a discrete grid, all the points in an epicentral zone are considered; each point is regarded as a possible epicenter. For each combination (epicenter, magnitude) all the parameters of isoseists - area, azimuth and elongation - are considered in succession. For each combination (epicenter, magnitude, parameters of isoseismals) the strong motion 
at each point of each object is determined. Corrections are introduced for ground conditions if they are known. The damage in each point is determined, and then the total damage from this earthquake.

As a result, for each possible combination (epicenter ; magnitude ; area, azimuth and elongation of isoseismals) we get a pair of numbers : $X-$ the total damage, $p-$ its probability. The value $p$ is the product of the probabilities of each parameter in the given combination. The set of pairs $(x, p)$ defines the distribution $F(x)$. Actual computational procedure is equivalent to this, but more economical : e.g. the variation of magnitude and area of isoseists can be considered jointly [4]. $F(x)$ refers to one arbitrary earthquake. We have also the distribution of the total number of earthquakes in the whole epicentral zone. From these two distributions the final result is obtained :

III. An estimation of seismic risk $F_{\Sigma}\left(D \mid T_{1}, T_{2} ; S\right)$ - distribution functions of the total damage $D$ from earthquakes.

The basic characteristic of this function are : average $m_{D}$ dispersion $\delta$ and a set of quantiles $x_{p}$ - the solution of the equation $F_{\Sigma}(D, T)=p$ for $p$ close to 1 . Roughly speaking, the total damage $D$ exceeds the level $x_{p}$ in $(1-p) \times 100$ cases out of 100 ; on the average it is equal to $m_{D}$.

The possible applications of such estimation of seismic risk are discussed in [3] and illustrated in $[5,6]$. The models are specified, depending on how the estimation is to be used : some problems require an extremal model, others - an average.

\section{The strong earthquakes in large cities}

a) A strong earthquake in a large city may amount to a disaster of a national scale, while a chain reaction of consequences may spread over the economy of the whole world [1]. The corresponding disaster-and-relief preparedness requires certain international endeavors. A comprehensive set of such endeavors, outlined under auspices of UNESCO and UNDRO, includes for example reinsurance, the planning of relief missions, the studies in earthquake prediction etc. [2]. The design of these endeavors requires the advance estimation of global seismic risk.

b) In this paper we estimate the seismic risk for the cities with population one million or more, situated in the active seismic belts of the world. Two measures of risk are considered. One measure, denoted $N$, shows how many such cities may be affected by the strong motion of macroseismic intensity $I \geqslant$ VIII degrees MM during 30 years. The second measure, denoted $D$, is the total number of people in these cities.

We include into the consideration only the earthquakes, which generate such strong motions on the area $\geqslant 100 \mathrm{~km}^{2}$, so that most probably the consequences are grave. Both $N$ and $D$ are considered as random values and their probabilistic distribution functions are estimated.

To test how reliable our estimations are, we compare them with the actual occurrence of past earthquakes. 
c) The estimation is made within the framework described in $[3,4,5]$; we follow the conception, methods and assumptions outlined there and use the corresponding computers software. The experience of regional studies of seismic risk $[5,6]$ is used to a large extent.

The only methodological amendment concerns the time dependence of the effect of a single earthquake. This time dependence is allowed for by the factor $\exp \left\{k\left(t-t_{0}\right)\right\}$, where $t$ is the time of an earthquake and $k-$ a real constant (rate of change); in the case considered here $k$ is the rate of the population growth. It was assumed previously that $k$ is the same for all objects. In the present study we remove this assumption, allowing for the fact that the rate of the population growth may be different for different cities. However, $k$ is assumed the same within a group of cities spaced so closely to each other that a single earthquake may cause VIII-degree shaking in two or more of them.

d) Our estimations are based on the global summaries of three sets of data: on seismicity, strong motions and the dynamics of population of the cities. The data on seismicity are compressed into the estimation of the parameters of frequency-of-occurrence law and maximal magnitude for each region of the world. This estimation and the corresponding seismotectonic regionalization of the world are described in details elsewhere [7]. On the strong motions we used so far the macroseismic data - the isoseists of intensity $I=$ VII, VIII and IX degrees, MM. These data were compressed into the model which represents the isoseists as ellipses with random parameters - area, orientation and elongation. Parameters of the model are estimated separately for different types of seismotectonic regions.

The data on demography are represented by population and the rate of population growth for each city.

All the data are collected from available publications and data files (except the global regionalization which is made in [7] especially for this study). Since the complete list of references would be forbinddingly large, we quote some sources only by the authors and publication year; only the major summaries are indicated for macroseismic data. The authors apologize for these forced omissions.

The authors are aware that the available data are far from being perfectly complete; the macroseismic data are especially fragmentary and the demographic data are especially speculative. However, the imperfection of data is partly compensated by the statistical approach, i.e. by consideration of the whole set of cities, and we hope that actual values of $N$ and $D$ lie within the estimated limits for all the cities together (though hardly for each separate city). This is confirmed by the satisfactory agreement between our estimations and actual earthquake history.

e) In the pilot study published previously [8], we considered the analogous problem for $I \geqslant I X$ degrees MM. The estimations for $I \geqslant$ VIII, presented here, have the advantage of being :

- more to the point, since intensity VIII on the area $\geqslant 100 \mathrm{~km}^{2}$ in a large city does spell disaster ;

- more reliable, since the data base is wider - both for the estimation of seismic risk and, most important, for comparison of results with past earthquakes ;

- more stable, since we may consider more cities ( 76 instead of 52 for $I \geqslant I X$ ). 


\section{Tables and Figures}

Table 1: Estimated number $D$ of inhabitants of large cities

affected by strong earthquakes ( $\geqslant$ VIII degrees on $\geqslant 100 \mathrm{~km}^{2}$ ) during 1971-2000

\begin{tabular}{|c|c|c|c|c|c|c|}
\hline \multirow{3}{*}{ Category $(n$} & \multirow{3}{*}{$\begin{array}{l}\text { Total } \\
\text { popula- } \\
\text { tion, } \\
\text { mlns }\end{array}$} & \multicolumn{3}{|c|}{$D, \mathrm{mlns}$} & \multirow{3}{*}{$\begin{array}{l}\text { Probabi- } \\
\text { lity of } \\
\text { no } \\
\text { events }\end{array}$} & \multirow{3}{*}{$\begin{array}{c}\text { A } \\
\text { per } \\
100 \\
\text { years }\end{array}$} \\
\hline & & \multirow{2}{*}{$m_{D} \pm \delta_{D}$} & \multicolumn{2}{|c|}{$x_{D}(p)$} & & \\
\hline & & & $p=5 \%$ & $p=1 \%$ & & \\
\hline $\begin{array}{l}\text { 1. Exceptional risk } \\
\text { (Tokyo group, } \\
7 \text { cities) }\end{array}$ & 24 & $20 \pm 15.5$ & 48 & 65 & $8 \%$ & 8 \\
\hline 2. Very high risk (17) & 47 & $17 \pm 15$ & 46 & 65 & $8 \%$ & 8.6 \\
\hline 3. High risk (52) & 76 & $2.9 \pm 3.3$ & 9 & 15 & $28 \%$ & 4.3 \\
\hline All cities (76) & 147 & $40.1 \pm 21.6$ & 79.8 & 101.7 & $0.2 \%$ & 21 \\
\hline
\end{tabular}

Note. A is the average number of the earthquakes, which generate $J \geqslant$ VIII MMS at least in one of the cities, while the area of Vlll-degree isoseist is $\geqslant 100 \mathrm{~km}^{2}$.

Table 2 : Estimated number $N$ of large cities

affected by strong earthquakes ( $\geqslant V I I I$ degrees on $\geqslant 100 \mathrm{~km}^{2}$ ) in 30 years

\begin{tabular}{|l|c|c|c|c|}
\hline \multirow{2}{*}{ Category } & \multirow{2}{*}{\begin{tabular}{c} 
Number \\
of \\
\cline { 3 - 5 }
\end{tabular}} & cities & $m_{N} \pm \delta_{N}$ & \multicolumn{2}{|c|}{$x_{N}(p)$} \\
\cline { 3 - 5 } & & & $p=5 \%$ & $p=1 \%$ \\
\hline $\begin{array}{l}\text { 1. Exceptional risk } \\
\text { (Tokyo group) }\end{array}$ & 7 & $4.1 \pm 2.8$ & 10 & 13 \\
2. Very high risk & 17 & $2,6 \pm 1.7$ & 6 & 8 \\
3. High risk & 52 & $1.3 \pm 1.2$ & 4 & 6 \\
\hline All cities & 76 & $8.0 \pm 3.5$ & 15 & 18 \\
\hline
\end{tabular}

$m_{N}-$ average : $\delta_{N}-$ dispersion; $x_{N}(p)$ will not be exceeded with probability $(1-p)$. 
Table 3 : Comparison of theoretical and observed statistics of strong $(J \geqslant V I I I)$ earthquakes in large cities of the world.

a. 15 cities in 1701-1980 (according to the catalog in the Appendix)

\begin{tabular}{|c|c|c|c|c|c|c|c|c|c|c|c|c|}
\hline \multirow{2}{*}{\multicolumn{3}{|c|}{$\begin{array}{l}\text { Weights } \\
\text { for } \\
\text { categories }\end{array}$}} & \multicolumn{7}{|c|}{$\Delta T$} & \multirow{3}{*}{$m_{N} \pm \delta_{N}(\Delta T)$} & \multirow{3}{*}{$\chi_{\text {norm }}^{2}$} & \multirow{3}{*}{$\varepsilon_{\text {obs }}$} \\
\hline & & & \multirow{2}{*}{$\begin{array}{l}1701- \\
-1740\end{array}$} & \multirow{2}{*}{$\begin{array}{l}1741- \\
-1780\end{array}$} & \multirow{2}{*}{$\mid \begin{array}{l}1781- \\
-1820\end{array}$} & \multirow{2}{*}{$\begin{array}{l}1821- \\
-1860\end{array}$} & \multirow{2}{*}{$\begin{array}{l}1861- \\
-1900\end{array}$} & \multirow{2}{*}{$\begin{array}{l}1901- \\
-1940\end{array}$} & \multirow{2}{*}{$\begin{array}{l}1941- \\
-1980\end{array}$} & & & \\
\hline$!$ & + & $?$ & & & & & & & & & & \\
\hline 1 & 1 & 1 & 5 & 5 & 2 & 6 & 6 & 4 & 4 & $4.6 \pm 1.7$ & 5.7 & $<0.0001$ \\
\hline 1 & 1 & 0 & 3 & 5 & 2 & 5 & 4 & 2 & 3 & $3.9 \pm 1.2$ & 2.3 & 0.01 \\
\hline 1 & $1 / 2$ & 0 & 2 & 3.5 & 1.5 & 4 & 3 & 2 & 3 & $2.7 \pm 0.8$ & -0.1 & 0.48 \\
\hline 1 & 0 & 0 & 1 & 2 & 1 & 3 & 2 & 2 & 3 & $2 \pm 0.8$ & -1.0 & 0.92 \\
\hline \multicolumn{11}{|c|}{ Theoretical estimation : $m_{N} \pm \delta_{N}(\Delta T)=1.8 \pm 1.3$} & \multicolumn{2}{|c|}{$x=1.13$} \\
\hline
\end{tabular}

b. 52 cities in 1801-1980 (according to the catalog in the Appendix)

\begin{tabular}{|c|c|c|c|c|c|c|c|c|c|c|c|}
\hline \multirow{2}{*}{\multicolumn{3}{|c|}{$\begin{array}{l}\text { Weights } \\
\text { for } \\
\text { categories }\end{array}$}} & \multicolumn{6}{|c|}{$\Delta T$} & \multirow{3}{*}{$m_{N} \pm \delta_{N}(\Delta T)$} & \multirow{3}{*}{$\chi_{\text {norm }}^{2}$} & \multirow{3}{*}{$\varepsilon_{\mathrm{obs}}$} \\
\hline & & & \multirow{2}{*}{$\begin{array}{l}1801- \\
-1830\end{array}$} & \multirow{2}{*}{$\begin{array}{l}1831- \\
-1860\end{array}$} & \multirow{2}{*}{$\begin{array}{l}1861- \\
-1890\end{array}$} & \multirow{2}{*}{$\begin{array}{l}1891- \\
-1929\end{array}$} & \multirow{2}{*}{$\begin{array}{l}1921- \\
-1950\end{array}$} & \multirow{2}{*}{$\begin{array}{l}1951- \\
-1980\end{array}$} & & & \\
\hline$!$ & + & $?$ & & & & & & & & & \\
\hline 1 & 1 & 1 & 3 & 11 & 9 & 7 & 3 & 4 & $6.2 \pm 4.8$ & 13 & $<0.0001$ \\
\hline 1 & 1 & 0 & 3 & 5 & 5 & 6 & 0 & 3 & $3.7 \pm 2.0$ & 2.1 & 0.11 \\
\hline 1 & $1 / 2$ & 0 & 2.5 & 4 & 4.5 & 5.5 & 0 & 3 & $3.2 \pm 1.8$ & 0.3 & 0.30 \\
\hline 1 & 0 & 0 & 2 & 3 & 4 & 5 & 0 & 3 & $2.8 \pm 1.6$ & -0.2 & 0.51 \\
\hline \multicolumn{10}{|c|}{ Theoretical estimation : $m_{N} \pm \delta_{N}(\Delta T)=2.7 \pm 1.7$} & \multicolumn{2}{|c|}{$x=1.11$} \\
\hline
\end{tabular}

c. Tokyo in 1601-1980

\begin{tabular}{|c|c|c|c|c|c|c|}
\hline \multirow{2}{*}{ Intensity } & \multicolumn{7}{|c|}{$\Delta T$} & \\
\cline { 2 - 7 } & $\begin{array}{c}1601- \\
-1674\end{array}$ & $\begin{array}{c}1675- \\
-1748\end{array}$ & $\begin{array}{c}1749- \\
-1822\end{array}$ & $\begin{array}{c}1823- \\
-1896\end{array}$ & $\begin{array}{c}1897- \\
-1970\end{array}$ & $m_{N} \pm \delta_{N}(\Delta T)$ \\
\hline$I(J M A) \geqslant V-$ & 9 & 6 & 3 & 10 & 6 & $6.9 \pm 2.5$ \\
$I(J M A) \geqslant V$ & 9 & 4 & 3 & 10 & 5 & $6 \pm 2.9$ \\
\hline
\end{tabular}




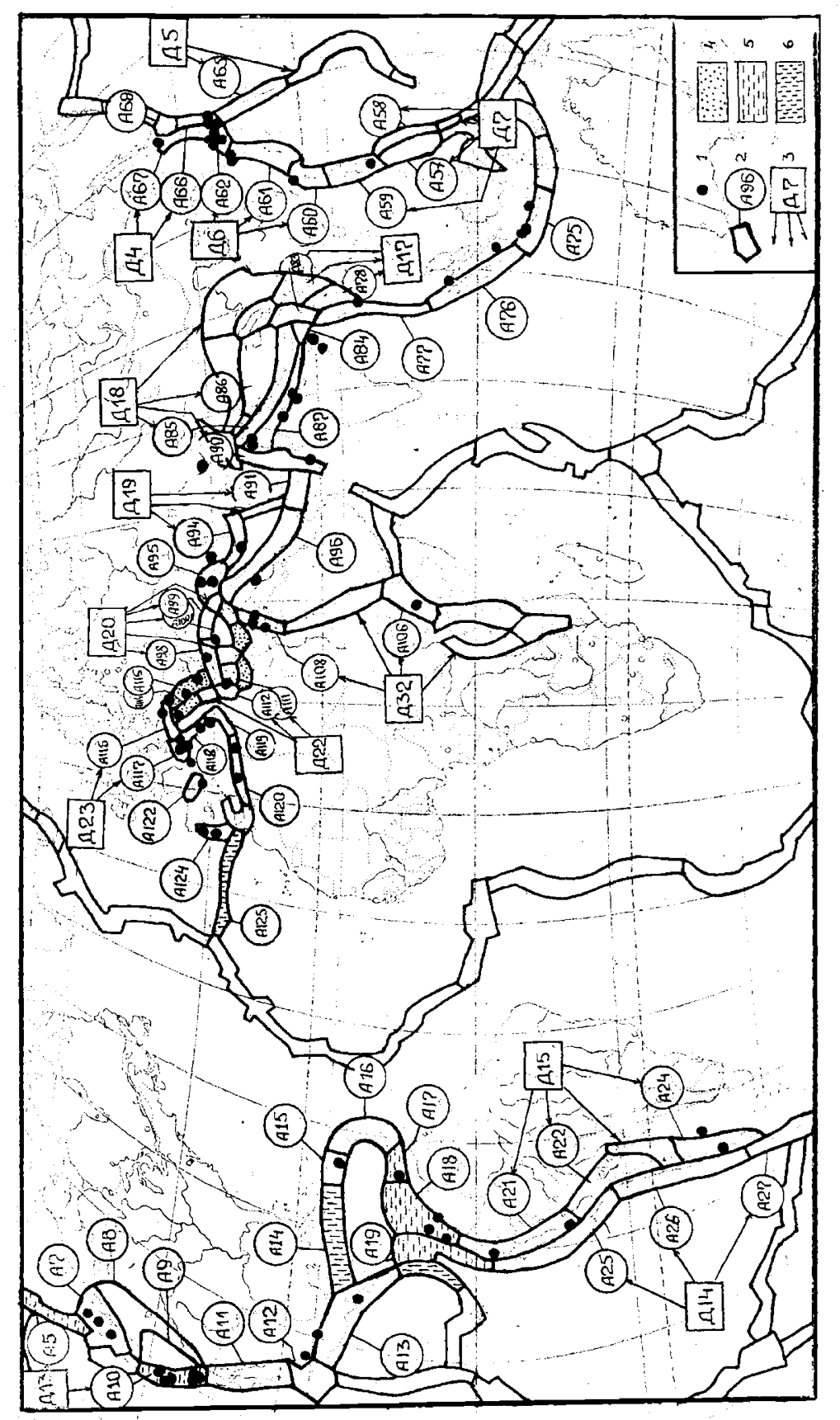

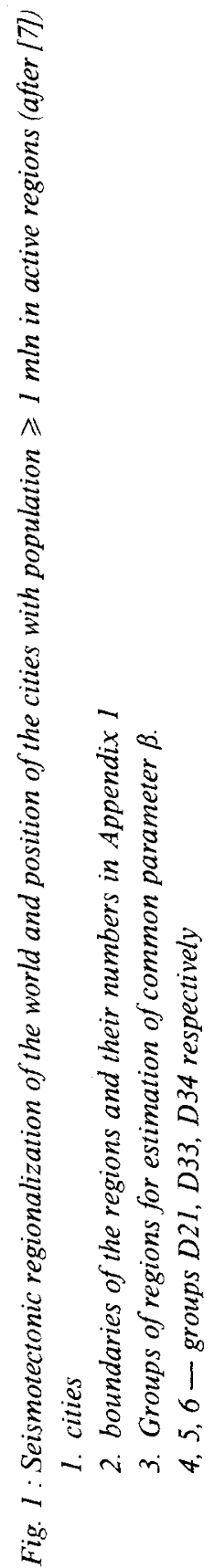




\section{Appendix 1}

\section{Models of seismicity and isoseists}

\begin{tabular}{|c|c|c|c|c|c|c|c|c|c|}
\hline \multirow{3}{*}{$\begin{array}{l}\text { Region } \\
\text { (fig. 1) }\end{array}$} & \multirow{3}{*}{$\begin{array}{c}\text { Group } \\
\text { of } \\
\text { regions } \\
\text { for the } \\
\text { esti- } \\
\text { mation } \\
\text { of }\end{array}$} & \multicolumn{5}{|c|}{ Seismicity } & \multicolumn{2}{|c|}{ Isoseists } & \multirow{3}{*}{$\begin{array}{l}\text { Cities, where the } \\
\text { earthquakes of the } \\
\text { region can generate } \\
J \geqslant \text { VIII on } \\
\geqslant 100 \mathrm{~km}^{2}\end{array}$} \\
\hline & & \multicolumn{3}{|c|}{$\begin{array}{l}\text { without } \\
\text { aftershocks }\end{array}$} & \multicolumn{2}{|c|}{$\begin{array}{l}\text { with } \\
\text { aftershocks }\end{array}$} & \multirow{2}{*}{$\begin{array}{l}\text { Azy- } \\
\text { muth, } \\
\text { Az }^{\circ}\end{array}$} & \multirow{2}{*}{$\mid \begin{array}{c}\text { Model } \\
\text { from } \\
\text { table 3 }\end{array}$} & \\
\hline & & $-\alpha$ & $\beta$ & $M_{\max }$ & $-\alpha$ & $\beta$ & & & \\
\hline 1 & 2 & 3 & 4 & 5 & \multicolumn{2}{|c|}{6} & 7 & 8 & 9 \\
\hline A5 & D 13 & 1.91 & 0.69 & 8.5 & 1.91 & 0.69 & 135 & Sa & Vancouver \\
\hline A 7 & A9 & 2.79 & 0.86 & 7.8 & 2.79 & 0.86 & $* * *$ & $\mathrm{H}$ & $\begin{array}{l}\text { Vancouver, Portland, } \\
\text { Seattle }\end{array}$ \\
\hline A8 & A9 & 3.04 & 0.86 & 7.5 & 3.04 & 0.86 & $* * *$ & $\mathrm{H}$ & $\begin{array}{l}\text { Vancouver, Portland, } \\
\text { Seattle }\end{array}$ \\
\hline A9 & A9 & 2.11 & 0.86 & 7.8 & 1.75 & 0.86 & $* * *$ & $\mathrm{H}$ & Sacramento \\
\hline A 10 & D13 & 2.31 & 0.54 & 8.5 & 2.06 & 0.69 & 135 & $\mathrm{Sa}$ & $\begin{array}{l}\text { San Francisco, San Jose, } \\
\text { Sacramento, Los Angeles, } \\
\text { San Diego, San Bernardino }\end{array}$ \\
\hline All & All & 2.10 & 0.69 & 7.3 & 1.79 & 0.81 & 150 & $\mathrm{AB}$ & $\begin{array}{l}\text { Los Angeles, San Diego, } \\
\text { San Bernardino }\end{array}$ \\
\hline $\mathrm{A} 12$ & $\mathrm{~A} 12$ & 1.85 & 0.66 & 8.6 & 1.75 & 0.68 & 105 & $\mathrm{Cb}$ & Guadalajara \\
\hline A 13 & A 13 & 2.10 & 0.56 & 8.9 & 1.83 & 0.66 & 105 & $\mathrm{Cb}$ & $\begin{array}{l}\text { Guadalajara, Guatemala, } \\
\text { Mexico }\end{array}$ \\
\hline A 14 & D34 & 2.94 & 0.71 & 7.9 & 2.94 & 0.71 & 75 & $\mathrm{Sa}$ & Guatemala \\
\hline A 15 & A 16 & 1.94 & 0.68 & 8.6 & 1.94 & 0.68 & 90 & $\mathrm{Cb}$ & San Juan \\
\hline A 16 & A 16 & 2.09 & 0.68 & 7.5 & 1.80 & 0.68 & 115 & $\mathrm{Cb}$ & San Juan \\
\hline A 17 & D33 & 2.61 & 0.72 & 8.4 & 2.61 & 0.72 & 90 & $\mathrm{Sb}$ & Caracas \\
\hline $\mathrm{A} 18 \mathrm{E}$ & D33 & 2.69 & 0.72 & 7.3 & 2.69 & 0.72 & 90 & $\mathrm{Sb}$ & Caracas \\
\hline A $18 \mathrm{~S}$ & D33 & 2.69 & 0.72 & 7.3 & 2.69 & 0.72 & 30 & $\mathrm{Sb}$ & Bogota, Cali, Medellin \\
\hline A 19 & A19 & 2.19 & 0.59 & 8.9 & 1.86 & 0.73 & 30 & $\mathrm{Sb}$ & Bogota, Cali, Medellin \\
\hline A19S & A19 & 2.19 & 0.59 & 8.9 & 1.86 & 0.73 & 15 & $\mathrm{Sb}$ & Guayaquil \\
\hline $\mathrm{A} 21 \mathrm{~N}$ & D15 & 2.49 & 0.61 & 8.4 & 2.28 & 0.68 & 15 & $\mathrm{H}$ & Cali, Guayaquil \\
\hline $\mathrm{A} 21 \mathrm{~S}$ & D15 & 2.49 & 0.61 & 8.9 & 2.28 & 0.68 & 135 & $\mathrm{H}$ & Lima \\
\hline $\mathrm{A} 22$ & D 15 & 2.90 & 0.61 & 7.9 & 2.78 & 0.68 & $* * *$ & $\mathrm{H}$ & Lima \\
\hline A24 & D 15 & 2.63 & 0.61 & 8.5 & 2.56 & 0.68 & 15 & $\mathrm{H}$ & Santiago, Cordoba \\
\hline
\end{tabular}




\begin{tabular}{|c|c|c|c|c|c|c|c|c|c|}
\hline 1 & 2 & 3 & 4 & 5 & 6 & & 7 & 8 & 9 \\
\hline $\mathrm{A} 25 \mathrm{~N}$ & A25 & 2.08 & 0.57 & 8.9 & 1.67 & 0.76 & 15 & $\mathrm{Cb}$ & Guayaquil \\
\hline A 25 & A 25 & 2.08 & 0.57 & 8.9 & 1.67 & 0.76 & 135 & $\mathrm{Cb}$ & Lima \\
\hline A 26 & D14 & 1.70 & 0.59 & 8.9 & 1.47 & 0.69 & 15 & $\mathrm{Ca}$ & Santiago \\
\hline A 27 & D14 & 1.98 & 0.59 & 8.9 & 1.98 & 0.69 & 15 & $\mathrm{Ca}$ & Santiago \\
\hline A 57 & D7 & 2.18 & 0.78 & 8.8 & 2.08 & 0.82 & 150 & $\mathrm{Cb}$ & Manila \\
\hline A 58 & D7 & 1.56 & 0.78 & 8.7 & 1.47 & 0.82 & 150 & $\mathrm{Cb}$ & Manila \\
\hline A59 & D7 & 1.66 & 0.78 & 8.0 & 1.47 & 0.82 & 150 & $\mathrm{Cb}$ & Manila \\
\hline A 60 & D6 & 1.32 & 0.64 & 8.8 & 1.23 & 0.67 & 15 & $\mathrm{Cb}$ & Taipei \\
\hline A61S & D6 & 1.87 & 0.64 & 8.4 & 1.88 & 0.67 & 90 & $\mathrm{Cb}$ & Taipei \\
\hline $\mathrm{A} 61 \mathrm{~N}$ & D6 & 1.87 & 0.64 & 8.4 & 1.88 & 0.67 & 30 & $\mathrm{Cb}$ & $\begin{array}{l}\text { Fukuoka, Kitakyushu, } \\
\text { Kobe, Kyoto, Osaka, } \\
\text { Nagoya }\end{array}$ \\
\hline A62 & D6 & 1.92 & 0.67 & 8.9 & 1.92 & 0.67 & 60 & Jap & $\begin{array}{l}\text { Kyoto, Kobe, Osaka, } \\
\text { Nagoya }\end{array}$ \\
\hline A65 & D5 & 1.80 & 0.85 & 8.5 & 1.67 & 0.92 & 150 & $\mathrm{Cb}$ & $\begin{array}{l}\text { Tokyo, Yokohama, } \\
\text { Kawasaki, Nagoya }\end{array}$ \\
\hline A66 & D4 & 1.41 & 0.61 & 8.9 & 1.45 & 0.63 & $* * *$ & $\mathrm{Cb}$ & $\begin{array}{l}\text { Tokyo, Yokohama, } \\
\text { Kawasaki, Kyoto, Kobe, } \\
\text { Osaka, Nagoya }\end{array}$ \\
\hline A67N & D4 & 2.10 & 0.63 & 8.2 & 2.10 & 0.63 & 15 & Jap & Sapporo \\
\hline A67S & D4 & 2.10 & 0.63 & 8.2 & 2.10 & 0.63 & 45 & Jap & $\begin{array}{l}\text { Tokyo, Kawasaki, } \\
\text { Yokohama, Nagoya }\end{array}$ \\
\hline A68 & A68 & 1.12 & 0.68 & 8.9 & 0.85 & 0.69 & $* * *$ & $\mathrm{Cb}$ & $\begin{array}{l}\text { Tokyo, Yokohama, } \\
\text { Kawasaki, Sapporo }\end{array}$ \\
\hline A75 & A75 & 1.72 & 1.08 & 8.1 & 1.63 & 1.14 & 105 & $\mathrm{Ca}$ & $\begin{array}{l}\text { Surabaja, Djakarta, } \\
\text { Bandung, Palembang }\end{array}$ \\
\hline A76 & A76 & 1.56 & 0.76 & 8.6 & 1.49 & 0.79 & 135 & $\mathrm{Ca}$ & $\begin{array}{l}\text { Djakarta, Bandung, } \\
\text { Palembang, Medan }\end{array}$ \\
\hline A77S & A77 & 1.81 & 0.92 & 8.9 & 1.81 & 0.92 & 130 & $\mathrm{Ca}$ & Medan \\
\hline $\mathrm{A} 77 \mathrm{~N}$ & A77 & 1.81 & 0.92 & 8.9 & 1.81 & 0.92 & 15 & $\mathrm{Ca}$ & Rangoon, Dacca \\
\hline A78 & D17 & 2.30 & 0.64 & 8.5 & 2.30 & 0.64 & 165 & $\mathrm{H}$ & Rangoon, Dacca \\
\hline A83 & D17 & 2.15 & 0.64 & 8.9 & 2.15 & 0.64 & $* * *$ & $\mathrm{H}$ & Rangoon, Dacca, Calcutta \\
\hline A84 & D1 & 2.00 & 0.64 & 8.1 & 2.00 & 0.64 & $* * *$ & $\mathrm{H}$ & Dacca, Calcuta \\
\hline
\end{tabular}




\begin{tabular}{|c|c|c|c|c|c|c|c|c|c|}
\hline 1 & 2 & 3 & 4 & 5 & 6 & 6 & 7 & 8 & 9 \\
\hline A85 & D18 & 1.90 & 0.74 & 8.9 & 1.67 & 0.81 & 120 & $\mathrm{H}$ & $\begin{array}{l}\text { Dacca, Calcutta, Lachnow, } \\
\text { Kanpur, Delhi, Lahore, } \\
\text { Lyallpur }\end{array}$ \\
\hline A86 & D18 & 2.37 & 0.74 & 8.5 & 2.28 & 0.81 & 120 & $\mathrm{H}$ & $\begin{array}{l}\text { Dacca, Calcutta, Delhi, } \\
\text { Lachnow, Kanpur, Lahore, } \\
\text { Lyallpur }\end{array}$ \\
\hline A87 & D18 & 2.36 & 0.81 & 7.4 & 2.35 & 0.81 & 120 & $\mathrm{H}$ & The same \\
\hline A90 & D18 & 2.05 & 0.74 & 8.0 & 1.82 & 0.81 & 15 & $\mathrm{H}$ & Lahore, Lyallpur, Carachi \\
\hline A91 & D19 & 2.25 & 0.78 & 8.8 & 2.25 & 0.78 & 75 & $\mathrm{H}$ & Karachi \\
\hline A94 & D19 & 2.15 & 0.78 & 7.8 & 2.15 & 0.78 & 75 & $\mathrm{H}$ & Tehran \\
\hline A95 & $* *$ & 2.20 & 0.92 & 7.5 & 2.20 & 0.92 & 105 & $* *$ & Tbilisi, Yerevan, Baku \\
\hline A96 & A96 & 1.84 & 0.97 & 7.8 & 1.78 & 0.97 & 135 & $\mathrm{H}$ & Baghdad \\
\hline A98 & D20 & 2.00 & 0.62 & 8.5 & 1.76 & 0.72 & 75 & $\mathrm{Sa}$ & Ankara, Instanbul, Aëtós \\
\hline A99 & D20 & 2.12 & 0.62 & 8.2 & 2.03 & 0.72 & 90 & $\mathrm{Sa}$ & Ankara \\
\hline A 100 & D20 & 2.36 & 0.62 & 7.1 & 2.24 & 0.72 & 90 & $\mathrm{Sa}$ & Ankara \\
\hline A106 & D32 & 2.11 & 0.72 & 7.5 & 2.11 & 0.72 & 30 & $\mathrm{AB}$ & Addis-Ababa \\
\hline A 108 & D32 & 3.29 & 0.72 & 6.8 & 3.23 & 0.72 & 15 & $\mathrm{AB}$ & Tel-Aviv, Beirut, Damascus \\
\hline A 111 & D22 & 1.92 & 0.80 & 8.0 & 1.81 & 0.83 & $* * *$ & $\mathrm{AH}$ & Aëtós \\
\hline Al12 & D22 & 1.55 & 0.80 & 7.5 & 1.37 & 0.80 & $* * *$ & $\mathrm{AH}$ & Aëtós \\
\hline A 114 & D21 & 2.01 & 0.96 & 8.3 & 1.95 & 0.99 & $* * *$ & $\mathrm{AH}$ & $\begin{array}{l}\text { Belgrad, Budapest, Zagreb, } \\
\text { Sofia }\end{array}$ \\
\hline A115 & D21 & 1.80 & 0.96 & 7.3 & 1.80 & 0.96 & 120 & $\mathrm{AB}$ & Zagreb \\
\hline A 116 & D23 & 2.36 & 0.95 & 6.5 & 2.36 & 0.95 & $* * *$ & $\mathrm{AB}$ & Vienna, Milan \\
\hline A 117 & D23 & 2.41 & 0.95 & 6.8 & 2.41 & 0.95 & $* * *$ & $\mathrm{AB}$ & $\begin{array}{l}\text { Genoa, Marseilles, Milan, } \\
\text { Turin }\end{array}$ \\
\hline A 118 & ** & 2.27 & 1.06 & 7.5 & 1.77 & 1.13 & 120 & $\mathrm{AB}$ & $\begin{array}{l}\text { Genoa, Milan, Naple, } \\
\text { Rome, Turin }\end{array}$ \\
\hline Al19 & $* *$ & 2.37 & 0.85 & 8.0 & 2.33 & 0.90 & 120 & $\mathrm{AB}$ & Naple \\
\hline A 120 & A 120 & 2.44 & 1.05 & 7.1 & 2.32 & 1.11 & 75 & $\mathrm{AH}$ & Alger, Tunis \\
\hline A 122 & A122 & 2.59 & 0.88 & 7.0 & 2.59 & 0.88 & 105 & $\mathrm{H}$ & Barcelona \\
\hline A 124 & Al 24 & 2.17 & 0.92 & 7.5 & 1.94 & 1.17 & 15 & $\mathrm{H}$ & Lisbon, Porto \\
\hline A 125 & D34 & 2.24 & 0.71 & 7.5 & 2.24 & 0.71 & 90 & $\mathrm{Sa}$ & Lisbon \\
\hline A 141 & $* *$ & 2.17 & 0.69 & 7.0 & 2.17 & 0.69 & $* * *$ & $\mathrm{H}$ & Tashkent \\
\hline
\end{tabular}

*) N, S, E or W - mean the corresponding part of the region.

**) Published data.

***) Azymuth is homogeneously distributed. 


\section{Appendix 2}

\section{Data on cities}

\begin{tabular}{|c|c|c|c|c|c|c|}
\hline \multirow{3}{*}{$\begin{array}{l}\text { Cities } \\
\text { (groups) }\end{array}$} & \multicolumn{3}{|c|}{ Demography } & \multirow{3}{*}{$\begin{array}{c}\lambda \\
\text { Number } \\
\text { of occur- } \\
\text { rences of } \\
J \geqslant \text { VIII } \\
\text { per } 1000 \\
\text { years }\end{array}$} & \multirow{2}{*}{\multicolumn{2}{|c|}{$\begin{array}{l}\text { Number of people } \\
\text { affected by } J \geqslant \text { VIII, } \\
\text { thousands per year }\end{array}$}} \\
\hline & \multirow{2}{*}{$\begin{array}{l}\text { Popula- } \\
\text { tion } \\
\text { mlns }\end{array}$} & \multicolumn{2}{|c|}{ Rate of growth } & & & \\
\hline & & $\mathrm{k} \%$ & $\underset{* *}{\operatorname{region}}$ & & $\begin{array}{l}\text { first } \\
\text { year }\end{array}$ & average \\
\hline 1 & 2 & 3 & 4 & 5 & 6 & 7 \\
\hline $\begin{array}{l}\text { The group of Tokyo } \\
(\mathrm{q}=45.2 \%)\end{array}$ & 24.1 & 0.12 & & 83.1 & 654 & 666 \\
\hline Large Tokyo & $15.7^{*}$ & & $\mathrm{c}$ & 79.2 & 643 & 654 \\
\hline Kyoto & $1.4^{*}$ & & $\mathrm{c}$ & 1.09 & 1.53 & 1.56 \\
\hline Kobe & $1,3^{*}$ & & $\mathrm{c}$ & 1.08 & 1.40 & 1.42 \\
\hline Osaka & $3.3^{*}$ & & $\mathrm{c}$ & 1.08 & 3.56 & 3.6 \\
\hline Nagoya & $2.4^{*}$ & & $\mathrm{c}$ & 2.34 & 5.6 & 5.7 \\
\hline $\begin{array}{l}\text { California group } \\
(\mathrm{q}=12.6 \%)\end{array}$ & 14.5 & 1.2 & & 15.2 & 44.6 & 53.6 \\
\hline Los Angeles & $7.0^{*}$ & & $\mathrm{c}$ & 3.14 & 22.0 & 26.5 \\
\hline San Bernardino & 1.1 & & - & 3.15 & 3.46 & 4.2 \\
\hline San Diego & 1.4 & & - & 3.54 & 4.96 & 6.0 \\
\hline San Francisco & $3.1^{*}$ & & $\mathrm{c}$ & 3.16 & 10.1 & 12.2 \\
\hline Sacramento & 0.8 & & - & 1.04 & 0.83 & 1.0 \\
\hline San José & 1.1 & & - & 3.28 & 3.61 & 4.3 \\
\hline Manila & $4.1^{*}$ & 6.5 & $\mathrm{c}$ & 9.06 & 37.2 & 115 \\
\hline Taipei & $1.8^{*}$ & 6.8 & $\mathrm{c}$ & 17.9 & 32.2 & 106 \\
\hline Lima & $3.3^{*}$ & 6.2 & $\mathrm{c}$ & 10.4 & 34.3 & 99.8 \\
\hline Mexico group $(q=1 \%)$ & 10.0 & 5.6 & & 4.3 & 31.2 & 80.7 \\
\hline Mexico & $8.6^{*}$ & & $\mathrm{c}$ & 3.49 & 30.0 & 78.0 \\
\hline Guadalajara & 1.4 & & c & 0.86 & 1.2 & 3.1 \\
\hline Santiago & $3.1^{*}$ & 3.9 & $\mathrm{c}$ & 5.38 & 16.7 & 31.3 \\
\hline Djakarta group $(q=5.9 \%)$ & 6.6 & 3.9 & & 5.35 & 15.4 & 28.9 \\
\hline Djakarta & 4.6 & & $\mathrm{c}$ & 2.51 & 11.5 & 21.8 \\
\hline Bandung & 1.2 & & $\mathrm{c}$ & 3.16 & 3.8 & 7.2 \\
\hline Palembang & 0.8 & & - & 0.007 & 0.006 & 0.01 \\
\hline
\end{tabular}




\begin{tabular}{|c|c|c|c|c|c|c|}
\hline 1 & 2 & 3 & 4 & 5 & 6 & 7 \\
\hline Instanbul & 2.7 & 5.9 & $\mathrm{c}$ & 5.07 & 13.2 & 36.7 \\
\hline Guatemala & 0.8 & 4.4 & $\begin{array}{c}\text { Lat. } \\
\text { America }\end{array}$ & 12.8 & 10.2 & 21.8 \\
\hline Addis-Ababa & 0.9 & 4.9 & Africa & 4.61 & 4.15 & 9.51 \\
\hline Alger & 1.0 & 6.0 & Alger & 0.106 & 0.106 & 0.29 \\
\hline Ankara & $1.2^{*}$ & 6.7 & $\mathrm{c}$ & 1.07 & 1.28 & 4.31 \\
\hline Aëtos & 2.1 & 1.3 & c & 1.99 & 4.18 & 5.11 \\
\hline Baghdad & $1.2^{*}$ & 4.3 & $\mathrm{c}$ & 0.0002 & 0.0002 & 0.0005 \\
\hline Baku & $1.3^{*}$ & 2.2 & c & 0.002 & 0.003 & 0.004 \\
\hline Barcelona & $1.7^{*}$ & 1.1 & $\mathrm{c}$ & 0.046 & 0.08 & 0.09 \\
\hline Bogota group $(q=0.01 \%)$ & 5.7 & 5.1 & & 2.83 & 2.95 & 6.95 \\
\hline Bogota & 2.9 & & $\underset{\text { bia }}{\text { Colum- }}$ & 0.276 & 0.80 & 1.89 \\
\hline Kallia & 0.9 & & $\underset{\text { bia }}{\text { Colum- }}$ & 0.38 & 0.34 & 0.80 \\
\hline Medellin & 1.1 & & $\underset{\text { bia }}{\text { Colum- }}$ & 0.29 & 0.32 & 0.76 \\
\hline Guayaquil & 0.8 & & Ecuador & 1.89 & 1.51 & 3.57 \\
\hline Budapest group $(\mathrm{q}=0.8 \%)$ & 7.0 & 3.1 & & 3.51 & 4.25 & 6.95 \\
\hline Zagreb & 1.2 & & $\begin{array}{c}\text { Yugosla- } \\
\text { via }\end{array}$ & 1.02 & 1.22 & 2.01 \\
\hline Belgrad & 1.2 & & $\begin{array}{c}\text { Yugosla- } \\
\text { via }\end{array}$ & 0.89 & 1.07 & 1.76 \\
\hline Budapest & 2.1 & & $\mathrm{c}$ & 0.062 & 0.13 & 0.21 \\
\hline Vienna & 1.6 & & $\mathrm{c}$ & 0.62 & 0.99 & 1.63 \\
\hline Sofia & 0.9 & & Bolgaria & 0.88 & 0.79 & 1.30 \\
\hline Beirut group $(q=1.5 \%)$ & 1.6 & 4.1 & & 0.4 & 0.32 & 0.64 \\
\hline Beirut & 0.8 & & Lebanon & 0.23 & 0.18 & 0.35 \\
\hline Damascus & 0.8 & & Syria & 0.18 & 0.14 & 0.28 \\
\hline Calcutta group $(\mathrm{q}=1.5 \%)$ & 16.7 & 2.9 & & 2.30 & 2.997 & 4.74 \\
\hline Calcutta & $7.0^{*}$ & & $\mathrm{c}$ & 0.0013 & 0.009 & 0.014 \\
\hline Dacca & $0.8^{*}$ & & - & 0.33 & 0.26 & 0.41 \\
\hline Delhi & $3.6^{*}$ & & $\mathrm{c}$ & 0.04 & 0.14 & 0.22 \\
\hline Kanpur & $1.3^{*}$ & . & $\mathrm{c}$ & 0.0053 & 0.007 & 0.01 \\
\hline
\end{tabular}




\begin{tabular}{|c|c|c|c|c|c|c|}
\hline 1 & 2 & 3 & 4 & 5 & 6 & 7 \\
\hline Lachnow & 0.8 & & - & 0.046 & 0.037 & 0.06 \\
\hline Lahore & 2.3 & & $\mathrm{c}$ & 0.20 & 0.40 & 0.73 \\
\hline Lyallpur & 0.9 & & - & 0.02 & 0.018 & 0.029 \\
\hline Rangoon & 1.2 & 2.9 & $\mathrm{c}$ & 1.69 & 2.03 & 3.24 \\
\hline Caracas & $2.2^{*}$ & 5.3 & $\mathrm{c}$ & 0.52 & 1.13 & 2.78 \\
\hline Karachi & 3.1 & 5.4 & $\mathrm{c}$ & 1.03 & 3.19 & 8.08 \\
\hline $\begin{array}{l}\text { Kitakyushu group } \\
(\mathrm{q}=33.6 \%) \\
\text { Kitakyushu } \\
\text { Fukuoka }\end{array}$ & $\begin{array}{l}1.9 \\
1.0 \\
0.9 \\
\end{array}$ & 2.5 & $\begin{array}{l}\text { Japan } \\
\text { Japan }\end{array}$ & $\begin{array}{l}2.01 \\
1.90 \\
0.79 \\
\end{array}$ & $\begin{array}{l}2.70 \\
1.90 \\
0.71 \\
\end{array}$ & $\begin{array}{l}3.99 \\
2.83 \\
1.06 \\
\end{array}$ \\
\hline Cordoba & 0.8 & 1.5 & $\begin{array}{l}\text { Argen- } \\
\text { tina }\end{array}$ & 0.0003 & 0.0002 & 0.0003 \\
\hline Lisbon & $1.6^{*}$ & 2.0 & $\mathrm{c}$ & 0.19 & 0.31 & 0.42 \\
\hline Marseilles & 1.1 & 2.7 & France & 0.097 & 0.11 & 0.16 \\
\hline Medan & 0.8 & 3.7 & $\begin{array}{l}\text { Indo- } \\
\text { nesia }\end{array}$ & 0.55 & 0.44 & 0.87 \\
\hline $\begin{array}{l}\text { Milan group }(q=0.3 \%) \\
\text { Milan } \\
\text { Turin } \\
\text { Genoa }\end{array}$ & $\begin{array}{l}3.8 \\
1.7 \\
1.2 \\
0.9\end{array}$ & 1.5 & $\begin{array}{l}\mathrm{c} \\
\mathrm{c} \\
-\end{array}$ & $\begin{array}{l}3.71 \\
1.16 \\
1.43 \\
1.13 \\
\end{array}$ & $\begin{array}{l}4.74 \\
1.97 \\
1.72 \\
1.02 \\
\end{array}$ & $\begin{array}{l}5.98 \\
2.49 \\
2.17 \\
1.29 \\
\end{array}$ \\
\hline Porto & 1.3 & 5.7 & $\mathrm{c}$ & 0.19 & 0.25 & 0.65 \\
\hline $\begin{array}{l}\text { Rome group }(\mathrm{q}=0.08 \%) \\
\text { Rome } \\
\text { Naples }\end{array}$ & $\begin{array}{l}4.0 \\
2.8 \\
1.2 \\
\end{array}$ & 2.2 & $\begin{array}{l}\mathrm{c} \\
\mathrm{c} \\
\end{array}$ & $\begin{array}{l}1.48 \\
1.18 \\
0.30 \\
\end{array}$ & $\begin{array}{l}3.68 \\
3.30 \\
0.36 \\
\end{array}$ & $\begin{array}{l}5.18 \\
4.67 \\
0.51\end{array}$ \\
\hline San Juan & 0.8 & 4.4 & $\begin{array}{c}\text { Lat. } \\
\text { America }\end{array}$ & 7.20 & 5.76 & 12.2 \\
\hline Sapporo & $1.2^{*}$ & 2.5 & Japan & 2.8 & 3.36 & 5.1 \\
\hline $\begin{array}{l}\text { Seattle group }(q=(0.5 \%) \\
\text { Seattle } \\
\text { Vancouver } \\
\text { Portland }\end{array}$ & $\begin{array}{l}3.4 \\
1.4^{*} \\
1.0 \\
1.0\end{array}$ & 1.8 & $\begin{array}{c}\text { USA } \\
\text { Canada } \\
\text { USA }\end{array}$ & $\begin{array}{l}0.25 \\
0.083 \\
0.083 \\
0.083 \\
\end{array}$ & $\begin{array}{l}0.29 \\
0.12 \\
0.08 \\
0.08 \\
\end{array}$ & $\begin{array}{l}0.37 \\
0.16 \\
0.11 \\
0.11\end{array}$ \\
\hline Surabaja & 1.6 & 3.2 & $\mathrm{c}$ & 0.0046 & 0.0007 & 0.005 \\
\hline
\end{tabular}




\begin{tabular}{|l|c|c|c|c|c|c|}
\hline \multicolumn{1}{|c|}{1} & 2 & 3 & 4 & 5 & 6 & 7 \\
\hline Tashkent & 1.4 & 2.8 & $\mathrm{c}$ & 0.59 & 0.83 & 1.27 \\
\hline Tbilisi group $(\mathrm{q}=0.1 \%)$ & 1.7 & 2.6 & & 4.17 & 3.45 & 1.27 \\
$\quad$ Tbilisi & 0.9 & & $\mathrm{c}$ & 2.05 & 1.84 & 2.79 \\
$\quad$ Yerevan & 0.8 & & $\mathrm{c}$ & 2.13 & 1.70 & 2.58 \\
\hline Tehran & 3.2 & 6.0 & $\mathrm{c}$ & 0.59 & 1.89 & 5.20 \\
\hline Tel-Aviv & 0.9 & 4.8 & Israel & 0.18 & 0.16 & 0.36 \\
\hline Tunis & 0.7 & 3.2 & $\mathrm{c}$ & 0.11 & 0.08 & 0.13 \\
\hline
\end{tabular}

*) Data on the city within the agglomeration.

**) " c" — city limits ; “ - " — no data.

Notations : $\mathrm{q}$ - dependence in a group (described in the text). 